\title{
Article
}

\section{The Education of Informal Educators}

\author{
Tony Jeffs ${ }^{1, *}$ and Mark K. Smith ${ }^{2}$ \\ 1 Department of Sociology, Durham University, Durham DH1 3LE, UK \\ 2 The Encyclopedia of Pedagogy and Informal Education [infed.org]; Orkney KW17 2SW, UK; \\ markksmith@outlook.com \\ * Correspondence: aj.jeffs@btconnect.com
}

check for

updates

Citation: Jeffs, T.; Smith, M.K. The Education of Informal Educators. Educ. Sci. 2021, 11, 488. https:// doi.org/10.3390/educsci11090488

Academic Editors: Mike Joy, Pam Alldred and Frances Howard

Received: 15 June 2021

Accepted: 18 August 2021

Published: 1 September 2021

Publisher's Note: MDPI stays neutral with regard to jurisdictional claims in published maps and institutional affiliations.

Copyright: (c) 2021 by the authors. Licensee MDPI, Basel, Switzerland. This article is an open access article distributed under the terms and conditions of the Creative Commons Attribution (CC BY) license (https:// creativecommons.org/licenses/by/ $4.0 /)$.

\begin{abstract}
No undergraduate or postgraduate programmes currently exist for the professional education of informal educators. The authors outline the development of previous programmes and consider the emergence of informal education as a discrete concept. The article then highlights some key failings in the professional education of informal educators and outlines some changes in the orientation and content of programmes.
\end{abstract}

Keywords: informal education; professional education; pedagogy; group work; social pedagogy; YMCA

\section{Introduction}

Over the last fifty years, exploration of the processes and orientation of informal education has been erratic. The topic was researched for a short time in English primary education post-Plowden and was glimpsed in UK youth work in the 'Albemarle period' but only much later returned [1-3]. We find a more consistent presence within adult and lifelong education via Brookfield [4] on adult learning in the community; Coombs [5] on non-formal education; Kolb's [6] return to Dewey via experiential learning; and Lave and Wenger's work on situated learning [7]. There has, however, been a strong and continuing tradition of addressing pedagogic processes and orientations within continental European social work and care-and education more broadly. While this area of exploration has had a marginal impact upon care and social work training in the UK [8-10], it has been largely ignored or misunderstood within 'Anglo-American' traditions of thinking and practice concerning education [11].

This paper looks briefly at these arenas of practice and highlights three fundamental problems. The tendency on the part of both academics and practitioners to:

- Stay within familiar silos of thinking and practice that are both past their 'sell-by date' and lack an educational imagination.

- Avoid grounding exploration in the social thinking and moral philosophy necessary to root and guide practice as pedagogues and teachers.

- Pay inadequate attention to the subject matter of the teaching activities of informal educators.

The result overall is a profoundly misdirected professional education arena.

\section{Informal Education}

Predictably, we cannot vouchsafe the date when the term 'informal education' first surfaced but can say it has tended to be used in two main ways. The first is to describe educational activities taking place in non-school settings. The second usage delineates two contrasting processes of, and orientations to, facilitating learning-one largely instructional and organized by a curriculum, the other emerging from experience, reflection, and conversation. As John Dewey [12] put it, 'In what we have termed informal education, subject matter is carried directly in the matrix of social intercourse. It is what the persons 
with whom an individual associates do and say'. The challenge for Dewey was how best to balance informal and formal education, and incidental and intentional learning.

Within Anglo-American practice the development of thinking about how to prepare practitioners as informal educators has largely centred around the work of three groups of people. The first was a formidable set of academics following in John Dewey's footsteps and based in the American YMCA and YWCA in the 1920s and 1930s. The second was a similarly impressive group of women working in the UK at the National Association of Girls and Mixed Clubs during the 1940s. The earliest full-length treatment of informal education [13] grew out of their activities. The last group was based at, or connected with, the YMCA George Williams College in London. They drew on the work of the other two groups, added in contemporary contributions, and then developed, and ran the only dedicated professional development degree programmes in informal education in the world. Wrapped up with these were also developments in primary schooling, community education and specialist education.

\subsection{Chicago and Group Work}

We can see a focus on setting in the pioneering activities of staff teaching at George Williams College (Chicago) in the mid-1920s. Informal education or what was more often dubbed "recreational and informal education" emerged as a portmanteau term utilised to identify the educational work undertaken by settlement houses, youth-serving organisations (such as the YMCA, YWCA, uniformed groups, and the boys' and girls' clubs), neighbourhood centres, and adult education programmes. Interestingly, professional preparation programmes such as those based at George Williams College (Chicago) 'were grounded primarily in the educational philosophy of John Dewey' [14] but this had not fully found its way into the conceptualisation of informal education in use there.

George Williams College staff during the inter-war years were anxious to extend their portfolio of degree programmes and to offer courses that would equip individuals to work in the recreational and informal education sectors. However, rather than launch an informal education degree programme with specialist routes it opted to develop programmes linked to what they termed "social group work". Most of the key figures in the development of social group work either taught at the college-Hedley Dimock, Charles E. Hendry and Harleigh B. Trecker; or worked closely with it-Gertrude Wilson and Gladys Ryland (Chicago YWCA), Neva Boyd (Hull House Settlement, Chicago) and the doyen of group work theorists Grace Coyle who was employed by the YMCA for most of the 1920s and 1930s. Their reasoning for doing so was that:

Informal education leaders entered their fields with the assumption that small group face-to-face encounters provided the best context within which people, including children, could solve their common problems or set new goals. A well-functioning small group was seen as a powerful agency for change. Consequently, under the guidance of a skilled guide, these groups and their members were fully equipped to establish and pursue appropriate goals and/or solve problems encountered in their paths. With help, young people in particular, could be led to discover, intelligently respond to and better manage the challenges and opportunities they faced. [14]

The decision clearly reflected a desire to equip graduates with a skill set that would enable them to survive in highly demanding settings. This was a period when youth serving organisations often found themselves catering for numbers that are not currently encountered. Chicago YMCA in the 1930s had a membership of 32,000 and operated from a thirteen-storey headquarters plus five large outreach centres. The boys' club run by Hull House Settlement nearby to the College-and a venue where students undertook placements - had a membership of 1500 [15]. Social group work was viewed as a method that would enable a restricted number of professional workers to operate with large numbers to create educational opportunities and foster relationships. Besides the Chicago group, there were others working for the YMCA involved in developing thinking around informal and lifelong education in the States. Notably, these included two writers heavily 
influenced by Dewey-Eduard Lindeman [16] who briefly taught at George Williams College between 1918 and 1919 and Ruth Kotinsky [17] who worked for the National YMCA in the 1920s and 1930s [18]. Later they were followed by Malcolm Knowles who is now known for his work on andragogy but who also wrote Informal Adult Education [19].

\subsection{The National Association of Girls and Mixed Clubs}

The first book-length exploration of informal education appeared in 1946. Written by Josephine Macalister Brew, it argued that education should be taken 'to the places where people already congregate, to the public house, the licensed club, the dance hall, the library, the places where people feel at home' [13]. She explored how educators can 'insert' education into such units. In particular, she focused on what we might describe now as the process of creating and exploiting teaching moments. In an earlier book, she had started to explore how to do this:

Only by the slow and tactful method of inserting yourself unassumingly into the life of the club, not by talking to your club members, but by hanging about and learning from their conversation and occasionally, very occasionally, giving it that twist which leads it to your goal, is it possible to open up a new avenue of thought to them. [20]

Brew was a member of a talented team of women who during their time with NAGC\&MC and after they departed were prolific authors and influential practitioners. These included Eileen Younghusband (who was later to write several seminal books and reports in social work); Madeline Rooff, Lesley Sewell, Desiree Edwards-Rees and Pearl Jephcott — a gifted social researcher, worker, and organizer [21,22]. One of the significant features of this group is that while they were focused on work with young people, they had also been active in a range of settings including educational settlements, school, and university teaching, social research, social settlements, and social work, as well as youth work.

\subsection{YMCA George Williams College}

The only extant undergraduate or postgraduate degree programmes in 'informal education' appeared some sixty years after the Chicago pioneers. Developed by the YMCA George Williams College (London), these ran from 1992 to 2015 [23]. The programmes led to professional qualifications for both UK youth work and Community Learning and Development (CLD) (Scotland). From 2012 onwards the College developed a focus on pedagogy offering degrees, for example, in social pedagogy and in work with children, young people and families. YMCA George Williams College effectively closed in 2021 [23].

The College had been established in 1970 to train youth workers and developed a distinctive approach. In significant part this was shaped by M. Joan Tash, the senior tutor. At the core of the modus operandi lay an emphasis on the development of the whole person and the connectedness of human life. At one level this should not be surprising given the YMCA triangle of body, mind, and spirit, and the Humanics orientation of the first YMCA College opened in Springfield Massachusetts in 1885. Humanics being the term first employed to describe the broad syllabus developed by the College to train YMCA Secretaries via the study of human nature, relationships, and affairs [24,25]. Tash embraced a focus on process, reflection, individual supervision, and groupwork. Josephine Klein adopted a similar mix in the new Goldsmith's College training programme launched in 1965. However, there were also differences linked to their contrasting professional backgrounds (Klein's in sociological research and psychotherapy; Tash's in the YWCA, non-managerial supervision, and fieldwork research).

As a 'monotechnic' institution the College was unhampered by the 'research assessment' procedures that have blighted UK universities since the late 1980s. College tutors were free to focus on writing and commissioning material associated with the very worlds of practice their students engaged with [23]. Hence informal education became a focus for exploration and rethinking of the role, functioning and processes of education outside curriculum focused practice $[3,26]$; the nature of accompanying and helping was explored and debated [27-29]; the character of grassroots practice examined [30]; and the state of 
faith-based youth work investigated [31]. As was the case with the NAGMC group, staff were drawn from a wide range of academic and practice traditions but were operating within a framework created by membership of an international movement, and by links to a wide range of local, community-based organisations across the UK. In part, this arose from the College's work with the Rank Foundation, which between 1988 and 2017 funded an extensive array of long-term developmental projects.

The College had recognized that a return to John Dewey and others' concern with community, process and orientation was needed. Furthermore, there was an appreciation that delineation between informal and formal education could be traced back to ancient Greece and the different approaches and concerns linked to diadacts and pedagogues. The former were basically instructors (didáskalos) and their task was to teach their subject. Pedagogues (paidagögus) had two common roles. One was to be an accompanist or companion; the other, and more fundamental, task was to help their charges learn what it was to act well. This they did by a combination of, for example, conversation and disciplining. Greek pedagogues were, in short, moral guides [11]. Unfortunately, in recent Anglo-American usage, teaching and pedagogy became simplistically confused. The latter is commonly defined as the art and science of teaching [32] and the full contemporary meaning of pedagogy has thus been obscured.

\section{Youth Work}

Little effort was made in the youth work sector in the UK over the forty years following Brew's [13] work to locate and build upon informal education's theoretical roots or to explore what being an 'informal educator' might mean in practice. Post-war austerity significantly reduced funding for the work, and in the 1950s, programmes like the Duke of Edinburgh's Award Scheme attracted attention (Brew herself was one of the main contributors to the design of the scheme). Additionally, developments in US group work garnered interest-and US-based writers were joined by UK-based practitioners and researchers such as Josephine Klein $[33,34]$. Their work was marked by an ability to draw on contemporary research, engage in a sustained way with practice, and to connect with developments in social psychology and psychoanalysis.

With a growing moral panic around the behaviour of young people, the English government set up the enquiry that resulted in The Albemarle Report [35]. Significant expenditure upon training, employing a cadre of full-time workers, and building new youth centres followed. The Youth Service was seen as having two central functions: (a) the socialisation and social education of the mass of young people a majority of whom at the time of publication entered the workforce at age 15; and (b) the control and containment of a deviant minority. While there was talk of informal and social education, the terms were not defined or the relationship between them discussed in the report. Influential works by Goetschius and Tash [36] and Davis and Gibson [37] were to explore the nature of the later as a way of expressing process and purpose, but after the 1960s it too was rarely subjected to serious enquiry $[1,38]$.

Another long period of austerity, combined with the extension of schooling, and changing leisure habits and social attitudes, had brought about a substantial reduction in the number of young people involved in youth work from the late 1970s-especially amongst those aged 15 and above. Structural problems arising from deindustrialization, financialization, and growing deprivation and poverty were also taking their toll. 'Youth' was therefore no longer a consistently helpful organizing idea for intervention [39]. Yet, little effort was made to rethink training and practice and to address the elephant in room. Youth services had been established to offer leisure and educational opportunities to those over the school leaving age of 14 and up to 18 years who were in full-time employment. Most of this age range were now remaining (or in many instances trapped) in full-time education and displayed no sustained interest in youth service provision. Thus, the longterm decline in state-sponsored youth services was unlikely to be reversed, resulting in 
it withering away $[1,39]$. However, there remained a possibility that provision linked to religious and civil society groups may survive and even flourish [40,41].

\section{Schools, and Informal Education}

Within English primary education following the Plowden Report there was a brief flowering of practice that looked back to Dewey's concerns with experience, reflection, and exploration. Chapter Two of the report famously opened 'At the heart of the educational process lies the child' [42]. Such 'child-centred' education was often talked about as involving schools moving away from 'acting upon' students, to becoming places 'for growing and developing' [43].

The result was a growing focus on activity or discovery methods, and the use of group work - for example drawing on the work of Leslie Button [44] to develop active tutorial work, and later attempts to reform the primary school classroom [45]. We also saw the development of 'open' classrooms and schools [46,47]. Thereby, 'informal education' was gifted a recognised presence within many schools, particularly those with larger classrooms that allowed students to work collaboratively in groups with interventions from a team of teachers. 'Open' was often used in a rather literal sense - that of physical space - rather than as an orientation or being open to new ideas and experiences. Key writers like Lillian Weber explicitly drew on Dewey and his forerunners and their work was informed by contemporary social psychologists and educationalists like Susan Issacs, Jerome Bruner, and Basil Bernstein. Weber, for example, attended to setting, relationships and processes in her discussion of informal education:

Informal, as I understand it, refers to the setting, the arrangements, the teacher-child and child-child relationships that maintain, restimulate if necessary, and extend what is considered to be the most intense form of learning, the already existing child's way of learning through play and through the experiences he seeks out for himself. [48]

There was a major backlash against these developments in schools in both the USA and the UK [49]. In part, this was based on the growing political influence of product-oriented approaches fixated with the acquisition and testing of a narrowly defined band of core knowledge; and a focus on skilling. However, we can also see that many teachers and school administrators struggled with the sophistication and stance of informal educational practice-and the extent to which it put the control of learning into the hands of the learners. It entailed having to embrace and balance both a didactic and a pedagogic frame of reference. It involved cultivating an educational imagination.

In some places this orientation was linked to, or found an expression in, the development of community schools in England-notably in the Cambridgeshire village colleges and subsequently in Coventry and Leicestershire [50]. These initiatives both opened schools to local communities including enabling adults to learn languages etc. alongside young people, as well as providing facilities for the use of local groups. They also often included substantial youth work and adult education programmes located within the school [51]. With the rise of the national curriculum, a narrowing of focus, substantial cutbacks in funding and the transfer of schools from local authorities to trusts, informal education of this kind largely faded from view - although there are some examples remaining from later Scottish initiatives-particularly in rural and island communities.

\section{Adult Learning, Community Organization and Community Education}

Within many countries there had been a long tradition of what might be called community adult education. This had existed alongside autonomous adult learning and discussion groups, and opportunities for learning within community action and community development initiatives. The latter had become more visible in England at the same time as the exploration of informal education was at its height in primary schooling [52]. Influential examples of UK practice could be found in the work of Eric Midwinter with the Liverpool Education Priority Area $[53,54]$ and his establishment of the University of the Third Age in 1973; and Tom Lovett's work on adult education and community action [55-57] and 
in the establishment of Ulster People's College. In Scotland, we see the emergence of 'community education' as a way of thinking about, and integrating, the activities of youth workers, community organizers and adult educators-especially after the publication of The Alexander Report in 1975 [58].

Looking further afield-and emerging out of the need to examine the work of nongovernmental organisations like the YMCA and YWCA in development programmes - there was 'refinement' of the definition of education by a setting or organizing agent. Within bodies such as UNICEF it was being argued that formal educational systems had failed to adapt to the socio-economic changes around them [59]. The result was an influential classification that placed non-formal alongside formal and informal education.

Formal education: the hierarchically structured, chronologically graded 'education system', running from primary school through the university and including, in addition to general academic studies, a variety of specialized programmes and institutions for full-time technical and professional training.

Informal education: the truly lifelong process whereby every individual acquires attitudes, values, skills and knowledge from daily experience and the educative influences and resources in his or her environment-from family and neighbours, from work and play, from the marketplace, the library and the mass media.

Non-formal education: any organized educational activity outside the established formal system - whether operating separately or as an important feature of some broader and learning objectives. [5]

It provided a neat categorization for administrators and was attractive to some practitioners and academics perhaps because it appeared to chime with Illich's [60] argument for deschooling and Freire's [61] work on literacy, dialogue, and praxis. However, this categorization activity was deeply problematic pedagogically, especially in the way it mixed institutional settings with processes, and schooling with education [62]. Identical processes, for example, could be found in each of the categories. The same group discussion of ethics, for example, could be conducted in a university seminar room, a community centre, or around a table in a bar. It was in this context that Brookfield [4] undertook a seminal exploration of adult learning in the community which looked at deliberate processes aimed at learning that did not have closely specified goals. This took us neatly back to Dewey, and to using conversation as a major organizing idea for informal education and curriculum for formal.

\section{Stuck in Silos, and Lacking an Educational Imagination}

It was obvious to those who looked that practitioners in quite different sectorsresidential work, schooling, probation, community development, youth work, lifelong learning, and religious organisations-were engaged in informal education [2]. Most shared, even if they were unfamiliar with his writings, Dewey's concern with the enlargement and emancipation of experience, and with building a life in common; drew upon similar roots in liberal education; and placed a value on conversation and reflection. However, they were working in arenas of practice that often lacked the tools or understandings to recognize the worth of what they were trying to do.

One of the abiding features of contemporary organisations and fields of practice is the extent to which their members thoughts and actions are fragmented and ensnared. They are also commonly trapped in occupational silos as a consequence of professional training and cultures that place an emphasis on the supposed uniqueness of their mode of intervention. In this setting it is easy to ignore the commonalities of practice and shared realities that link crafts and professions. One key quality, as Richard Sennett [63] has pointed out, is an aspiration for quality. Another, according to Peter Korn is a concern with creativity, bringing 'something new and meaningful into the world' [64]. Silos result, all too often, in tunnel vision, failure to recognize risk and change, and inability to innovate [65]. 
As Daniel Kahneman [66] put it, 'We can be blind to the obvious, and we are also blind to our blindness'.

We can see this process at work in Scotland in the attempts to integrate adult education, community development and youth work following the Alexander Report [61] First, each of the groupings had fairly negative views of each other and different orientations. Adult education was organized around classes and teaching and had a largely middle-class clientele; community development workers focused on groups in deprived communities and were concerned with animation, advocacy and policy change; and youth workers tended to be based in clubs in working class areas and focused on the provision of activities [67]. There were constant complaints from each of the three arenas that the interests of their 'clients' were not being addressed. Second, it took some time for government agencies to define what they meant by 'community education' [68] and there was no coherent policy for integration, certainly not one that addressed 'the human relations issues arising out of ... interservice and inter-institutional rivalries' [69]. Third, Scotland, like many other countries, has experienced short phases of development followed by cuts and long periods of austerity often driven by decisions made in Westminster. Participative and reflective approaches to learning have been discarded under a strong central government emphasis upon schooling, skilling and datafication [70].

While there have been developments in the way we can understand and embrace informal education, they have not gained much traction either in the field or the academy. Too many have been unable to escape or even recognize the silos they are in. There were elements of this in the Scottish experience of community education even as the thinking about practice morphed into community learning and development. Practitioners and academics in the area had to deal with a strong, and ill-informed, emphasis on measurement and outcomes, and with an increasingly centralized state. That said, the framework developed in Scotland for professional education in community learning and development was more coherent and more appropriate to the needs of informal educators than that south of the border in youth work and community development [71]. It was, for example, used to shape the degree programmes in informal education already discussed at the YMCA George Williams College.

For all the talk of 'education' within the sectors that are our concern here there is a fundamental problem at their core, they lack an 'educational imagination'. Within AngloAmerican traditions there is a strong tendency to confuse education with schooling, and as we have already seen, teaching with pedagogy. Much schooling and teaching cannot be accurately described as 'education', neither can a great deal of youth work and community development work [72]. Many practitioners and academics lack a particular 'quality of mind' that enables them to frame 'what is going on in the world and of what may be happening within themselves' [73]. This is not just a case of thinking like an educator, but also of being one. It entails accepting that teaching and pedagogy, in each and every setting - formal and informal-is a calling, a vocation. It matters not if they occur via the medium of conversation, dialogue, role-modelling, or a PowerPoint, nor that it might take place in a community group, club, out on the street, in a corridor, classroom or wherever; the how and where are unimportant if the practitioner accepts that it is in essence a calling and a craft. In an inspirational passage, worth quoting at length, George Steiner encapsulates much of this reality in relation to teaching.

To teach seriously is to lay hands on what is most vital in a human being. It is to seek access to the quick and the innermost of a child's or an adult's integrity ... Poor teaching, pedagogic routine, a style of instruction which is, consciously or not, cynical in its merely utilitarian aims, are ruinous. They tear up hope by its roots. Bad teaching is, almost literally murderous and, metaphorically, a sin. It diminishes the student, it reduces to gray inanity the subject being presented. It drips into the child's or the adult's sensibility that most corrosive of acids, boredom, the marsh gas of ennui. Millions have had mathematics, poetry, logical thinking killed for them by dead teaching, by the perhaps subconsciously vengeful mediocrity of frustrated pedagogues .... In actual fact, as we 
know, the majority of those to whom we entrust our children in secondary education, to whom we look for guidance and example in the academy, are more or less amiable gravediggers. They labour to diminish their students to their own level of indifferent fatigue. They do not "open Delphi" but close it. [74]

This absence of educational imagination is not limited to the formal sectors of education but is also a feature of professional training courses through much of the informal sector.

What, then, does the educational imagination involve?

First, as can be seen in Figure 1, it entails what Joe Sachs [75] talks about as an 'active condition' and what Aristotle discusses as hexis: a readiness to sense and know. It also entails a calling to act. Second, it requires a guiding eidos or leading idea. John Dewey [12] classically talked about educators engaging with people 'to enable them to share in a common life' and, in Aristotle's terms, to flourish. Third, there is a disposition, what in German traditions of social pedagogy is described as haltung or stance [76]. Pedagogues are called to act in the belief that, as Bertold Brecht put it some time ago, 'when taking up a proper bearing, truth ... will manifest itself." [77]. Here we can describe this as a concern and a calling to act respectfully, knowledgeably, and wisely. A focus on dialogue and learning, and action that is informed and committed flows from this orientation [78].

Educators are

They work

Their concern is to act

With others they build

They encourage

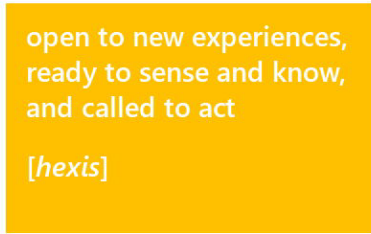

believing all should share in life and flourish

[eudaimonia]

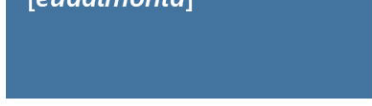

respectfully, holistically, knowledgeably, cooperatively and wisely [phronesis]

relationships and environments for dialogue, reflection and understanding.

[dialogos]

informed, committed action

[praxis] state / active condition

belief

disposition /

haltung

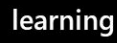

\section{change}

Figure 1. The educational imagination.

\section{Little Grounding in Social Sciences and Moral Philosophy}

Once we recognise that at the core of education is a stance or haltung that requires practitioners to act respectfully, knowledgeably, and wisely, it becomes clear why a solid grounding in the social sciences or what Barrow [79] refers to as the foundational disciplines, psychology, sociology, history, and philosophy, are essential for all those involved in 
education, in any setting. Without these and a moral philosophy we cannot respond to situations appropriately. We will lack the means to make sound judgements. This understanding was central to the activities of the Chicago pioneers of training for informal education and social groupwork in the 1930s. Sadly, it has been lost (or never found) in many professional programmes. A growing emphasis on skills, delivery, set procedures, and the measurement of predetermined outcomes tends to substitute often ill-informed technical objectives for dialogue and the emergence of wisdom.

'Good teaching', Parker J Palmer [80] argued, 'cannot be reduced to technique; good teaching comes from the identity and integrity of the teacher'. The same can be said of helping relationships generally [29] and for informal educators and pedagogues specifically. The Social Pedagogy Professional Association, for example, expects a particular philosophy and haltung to be 'held in a [pedagogue's] heart and guide their way of living and working' [81]. Palmer talks about good teachers (and here we can add pedagogues) possessing a capacity for connectedness.

They are able to weave a complex web of connections among themselves, their subjects, and their students so that students can learn to weave a world for themselves... The connections made by good teachers are held not in their methods but in their heartsmeaning heart in its ancient sense, as the place where intellect and emotion and spirit and will converge in the human self. [80]

These ways of talking about teachers and pedagogues do not sit well with the current orthodoxies within schooling, social work, community learning and development, and youth work. Within professional training for these areas, inadequate attention has been given to the 'who' or selfhood of the practitioner, and their interconnectedness with others and the world around them. Wrapped up with this, scant consideration has been given to deepening and extending practitioner's appreciation of moral philosophy, social psychology, social anthropology, social policy, economics, and the historical origins of contemporary practice. The overall result is that practitioners struggle to form an identity and frame of reference as educators and pedagogues (and get stuck in silos); lack the knowledge and disposition to make informed judgements and formulate useful theory; and are more likely to fall in line with policies and procedures that disadvantage the individuals and communities they are working with. As Quintilian, writing in the first century A.D., warned:

Let no one however demand from me a rigid code of rules such as most authors of textbooks have laid down... Most rules are liable to be altered by the nature of the case, circumstances of time and place, and by hard necessity itself... Rules are rarely of such a kind that their validity cannot be shaken and overthrown in some particular or other. [82]

Quite aside from a fundamental misunderstanding of the nature of education and pedagogy, there are also forces within higher education institutions that have contributed to the failure to ground student practitioners in the basics and develop professional identity. These include a growing tendency to view course participants as customers rather than students; the use of modular degree programmes where 'customers' can mix and match courses according to their own tastes rather than what they need in order to be professional and meet the needs of those they work alongside — clients and colleagues alike; and a valuing within universities of the publication of 'research' over engagement with practice and the individuals, contexts and agencies doing so involves. In short, they have been unable to create an environment where students can grow and create together the knowledge, wisdom, and ability to connect and engage with people that are necessary for teaching and pedagogy.

\section{Problems of Content}

Linked to the above there flows a further failure in training for informal education. Programmes have not generally addressed the issue of what exactly those qualifying are 
competent to 'educate' others in. Informal educators look to experiences, conversations and 'teachable moments', they also engage in formal programmes of teaching. Formal and informal education are not separate entities, 'they are rather a continuum shading gradually into one another' [83]. All alike are involved in an improvisational endeavour. One that requires practitioners to possess an arsenal of knowledge or what Lucy Shuker and Naomi Thompson [84] dub 'literacies', which they can communicate to others in a logical and lucid manner. Therefore, they must be fluid, nimble and flexible to adapt to the ebbs and flows of conversation and dialogue, and the variability of the world around them. We therefore must ask, what are they equipped to 'teach'? There are two main things to consider here: the subject knowledge and understanding that flows from a grounding in the social sciences and moral philosophy, and the specialist knowledge and skills in particular areas. We will look at the latter first.

We will seek to illustrate this by considering in part the work of the many informal educators working outdoor education. It entails them running training and coaching programmes and being qualified in the activities they are facilitating and teaching. They must maintain and extend their skill levels, be up to date on developments in their specialisms and be regularly re-accredited. National standards and structures are in place to facilitate this. In this respect they are no different from the 'coaches' and 'instructors' they work in tandem with. In one setting, for example, all three must be competent to teach novices how to safely mount a horse, sit in the saddle and walk it out. However, educationalists, outdoor educators and informal educators must be equipped to do much more than instruct novices in the rudiments of riding.

For a start, they must be able to draw upon a well of experience, information and theory that allows them to explain this 'skill' and contextualise and locate it within a conceptual framework. Possessing that framework means when the opportunity arises, they can, for example, exploit it to reflect upon equine physiology, the history of the different breeds, the design and manufacture of saddles or animal psychology. Equally, the conversation accompanying the task and experience might be nurtured by the educator so as to enable the group to reflect upon the moral and ethical issues relating to the 'exploitation' of horses for human enjoyment by drawing on the ideas of writers and philosophers such as Peter Singer [85] or Erica Fudge [86]; or alternatively to a consideration of the aesthetics of horse-riding, or reflection on the rich array of art linked to the horse for instance the paintings of George Stubbs (1724-1806), Edwin Landseer (1802-1873) and Alfred Munnings (1878-1959) or the sculpture of G. F. Watts (1817-1904).

The range of topics that might arise from the ostensibly mundane series of tasks is boundless yet utilising the opportunity to exploit these for learning requires that the informal or outdoor educator possesses a deep appreciation of the theory and history of what they are teaching plus the facility to foster conversation and dialogue. In this context conversation must not be mistaken for idle chatter or banter which tends to manufacture winners and losers. Rather, it is what Michael Oakeshott calls 'an unrehearsed intellectual adventure' involving individuals freely coming together to share their thinking and experiences who are content to let thoughts 'take wing' [87]. It is this form of conversational adventure that accomplished informal and outdoor educators are equipped to nurture and nourish.

Of course, it does not end there. Eventually they will be taking the group riding in open country. At which point they will need to be armed with a knowledge, for example, of fauna and flora, agriculture, geology and local history. As the setting or group changes so will the mix of subject-matter to be drawn upon.

Alongside this concern with teaching and teachable moments, runs broader pedagogical stream. Pedagogy can be seen as a process of being alongside others or accompanying people as well as:

- Working to bring flourishing and relationship to life (animation).

- Caring for, and about, people (caring).

- $\quad$ Drawing out learning (education) (Figure 2) [72]. 


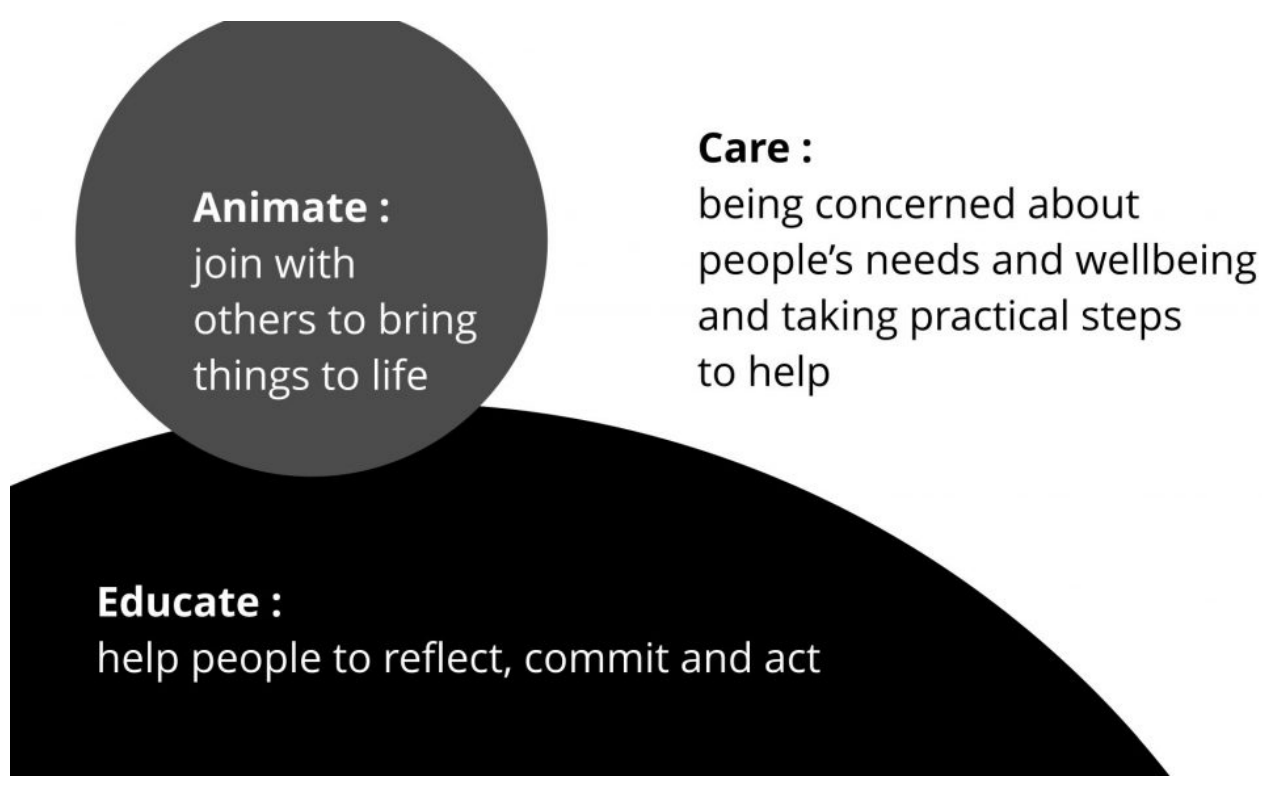

Figure 2. Animate, care, educate.

Many of the conversations in which pedagogues and informal educators participate involve questions that people have about how to deal with situations arising in their lives, relationships with others, and feelings about themselves. As Kerry Young [88] has pointed out, they involve the same question: how do I live life as well as I can? They are engaged with moral philosophy-and in a sense these conversations are the bread and butter of informal education and pedagogy. They require the ability to draw upon a broad range of knowledge. This includes:

- Appreciating the various elements that can contribute to people's happiness.

- Knowing how to animate and work with others to reflect on their situations and experiences and form judgements about what might lead to their, and others, flourishing.

- Being familiar with what is required to encourage and support action.

This adds up to a formidable body of expertise.

Alongside all this there are practical tasks of helping and care (which in turn require knowledge, skill and a particular haltung). Tasks can range from sorting out food for them to eat, and clothes to wear, to direct physical assistance with mobility and other everyday actions. In these days of austerity with cutbacks in care budgets and growing poverty, many schools and community organisations have had to make a sustained response in these areas, and this has led to some fundamental questions about future priorities.

We are not implying that informal educators must be polymaths who know everything about everything. Rather, that they must be able to lay claim to a rich and broad general education and be an ardent scholar ceaselessly searching out new ideas, information, and experiences. We would argue that the essential starting point for those seeking to become a professional pedagogue and informal educator should be a three-year degree in the Liberal Arts comprising five key strands:

- Humanities - including art, literature, linguistics, philosophy, religion, music, language;

- Social Sciences-including history, psychology, sociology, law, politics, economics, informatics;

- Natural Sciences - including astronomy, biology, chemistry, physics, botany, zoology, geology, earth sciences;

- Formal Science-including mathematics, logic, statistics.

- Reflection and Dialogue-including listening to, and engaging with, ourselves and others, whatever the context; exploring the processes of deepening understanding and making judgements; and fostering wisdom. 
Undergraduate Liberal Arts programmes, which have long been popular in the United States, already exist in the UK, therefore the basis exists for the creation of such a model. Upon completion of the undergraduate programme potential entrants could then undertake a one-year post-graduate programme that focussed on pedagogy, teaching, and informal education.

It is here that the full implications of the failure of programmes to ground practitioners in the liberal arts, social sciences and moral philosophy become clear. It is not just that they have been sold short in terms of their ability to be teachers and pedagogues, they have also lost the chance to develop their subject knowledge. David Hume after reading the accessible yet informative essays of the journalist Joseph Addison vowed to ensure that henceforth he would endeavour to write with similar clarity so that he might become a 'a kind of resident or ambassador from the dominion of learning to those of conversation; and shall think it my duty to promote good correspondence betwixt these two states, which have so great a dependence on each other' [89]. This ambassadorial role is in essence the function of the informal educator. However, to fulfil that role they must be in possession of the learning required to make a meaningful contribution to the conversations they partake in.

\section{Conclusions}

It is difficult to envisage that programmes of the sort discussed here will be unveiled soon. The demise of courses should not unduly amaze us. It has always been the case that the popularity of subjects wax and wane. For example, forty years ago there were over 70 undergraduate and postgraduate Humanics degrees running in North America. Linked to these were thriving university departments, scholarly journals, annual conferences, and a national accrediting body. Today nothing remains but a handful of stand-alone optional modules provided for under-graduate students by lone colleges scattered across the USA. To all intents and purposes, the subject has vanished from view. Similarly in the UK during the 1970s around a quarter of universities provided courses, nearly all postgraduate, in adult education. Most were designed to prepare students to work in a then thriving adult education sector. Today the courses and the sector alike have become all but extinct.

Given the decade long year-on-year fall in both the number of courses and students in attendance it seems likely that within a few years secular youth work education in the UK will suffer the same fate as adult education, play work and community work professional education. Christian youth work degree programmes may be all that remains, but their numbers have also dwindled, but at a markedly lower pace [90]. Whether or not that is the case, what might be loosely termed the 'informal education' sector within Higher Education is experiencing a period of prolonged crisis. Of course, that does not mean that informal education as an activity and pedagogical genre is teetering on extinction. Indeed, the current absence of an informal education presence in higher education should be viewed as an opportunity to think afresh regarding what it might be; to ask ourselves the crucial questions as to what might we expect a well-educated informal educator to know? Then, we can proceed accordingly.

Author Contributions: Jointly conceptualized, researched and written. Both authors have read and agreed to the published version of the manuscript.

Funding: This research received no external funding.

Institutional Review Board Statement: Not applicable.

Informed Consent Statement: Not applicable.

Data Availability Statement: Not applicable.

Acknowledgments: Figure 1 is reproduced with permission from Smith (2021) [81], Figure 2 from Smith 2019 [75].

Conflicts of Interest: The authors declare no conflict of interest. 


\section{References}

1. Smith, M. Developing Youth Work. Informal Education, Mutual Aid and Popular Practice; Open University Press: Milton Keynes, UK, 1988; pp. pp. 65-87, pp. 88-105.

2. Jeffs, T.; Smith, M. Using Informal Education. An Alternative to Casework, Teaching and Control? Open University Press: Milton Keynes, UK, 1990; pp. pp. 39, 105-107.

3. Jeffs, T.; Smith, M.K. Informal Education: Conversation, Democracy, and Learning, 3rd ed.; Educational Heretics: Ticknall, UK, 2005.

4. Brookfield, S. Adult Learners, Adult Education and the Community; McGraw-Hill Education: New York, NY, USA, 1984.

5. Coombs, P.H.; Prosser, R.; Ahmed, M. New Paths to Learning; International Council for Educational Development/UNICEF: New York, NY, USA, 1973.

6. Kolb, D.A. Experiential Learning; Prentice Hall: Englewood Cliffs, NJ, USA, 1984.

7. Lave, J.; Wenger, E. Situated Learning. Legitimate Peripheral Participation; University of Cambridge Press: Cambridge, UK, 1991.

8. Charfe, L.; Gardner, A. Social Pedagogy and Social Work; Sage: London, UK, 2019.

9. Hatton, K. Social Pedagogy in the UK: Theory and Practice; Russell House Publishing: Lyme Regis, UK, 2013.

10. Smith, M.; Whyte, B. Social education and social pedagogy: Reclaiming a Scottish tradition in social work. Eur. J. Soc. Work. 2008, 11, 15-28. [CrossRef]

11. Smith, M.K. What is pedagogy? In The Encyclopedia of Pedagogy and Informal Education. Available online: https://infed.org/ mobi/what-is-pedagogy/ (accessed on 13 May 2021).

12. Dewey, J. Democracy and Education. An Introduction to the Philosophy of Education. Project Gutenberg. 2015. First published in 1916. Available online: https:/ / www.gutenberg.org/ebooks/ 852 (accessed on 13 May 2021).

13. Brew, J.M. Informal Education. Adventures and Reflections; Faber: London, UK, 1946; p. 22.

14. Yerkes, R.; Miranda, W. Enduring Vision: From an Encampment to a Distinctive College. A History of George Williams College 1884-1961; George Williams College Press: Aurora, IL, USA, 2013; p. 134.

15. Alcorn, S. Strong Roots: A Group Memoir of George Williams College; George Williams Press: Williams Bay Wisconsin, WI, USA, 2007.

16. Lindeman, E.C. The Meaning of Adult Education; University of Oklahoma: Norman, OK, USA, 1989.

17. Kotinsky, R. Adult Education and The Social Scene; D. Appleton-Century Co.: New York, NY, USA, 1933.

18. Smith, M.K. Ruth Kotinsky on adult education and lifelong learning. In The Encyclopedia of Pedagogy and Informal Education. Available online: https://infed.org/mobi/ruth-kotinsky-on-adult-education-and-lifelong-learning/ (accessed on 31 May 2021).

19. Knowles, M.S. Informal Adult Education; Association Press: New York, NY, USA, 1950.

20. Brew, J.M. In the Service of Youth. A Practical Manual of Work among Adolescents; Faber: London, UK, $1943 ;$ p. 16.

21. Jeffs, T. Pearl Jephcott: Girls' club worker. Women's Hist Rev 2019, 28, 746-761. Available online: https: / / www.tandfonline.com/ doi/full/10.1080/09612025.2018.1472891?src=recsys (accessed on 22 May 2021).

22. Smith, M.K. Pearl Jephcott, youth and the lives of ordinary people. In The Encyclopedia of Pedagogy and Informal Education. 2020. Available online: https:/ /infed.org/mobi/pearl-jephcott-youth-and-the-lives-of-ordinary-people/ (accessed on 15 May 2021).

23. Jeffs, T. YMCA and Youth Work Education. In Youth and Policy. Available online: https://www.youthandpolicy.org/articles/ ymca-youth-work-education/ (accessed on 20 May 2021).

24. Doggett, L.L. Man and a School; Associated Press: New York, NY, USA, 1943.

25. Hall, L.K. Doggett of Springfield; Springfield College: Springfield, MA, USA, 1964.

26. Deer-Richardson, L.; Wolfe, M. (Eds.) Informal Education and Lifelong Learning: Principles and Practice; Routledge: London, UK, 2001.

27. Christian, C.; Green, M. Accompanying Young People on Their Spiritual Quest; The National Society/Church House Publishing: London, UK, 1998.

28. Smith, H. Seeking Out the Gift of Authenticity. In Youth and Policy 77. pp. 19-32, Also Available as an Article in The Encyclopedia of Pedagogy and Informal Education. 2002. Available online: https://infed.org/mobi/seeking-out-the-gift-of-authenticity/ (accessed on 15 May 2021).

29. Smith, H.; Smith, M.K. The Art of Helping Others. Being Around, Being There, Being Wise; Jessica Kingsley: London, UK, 2008; pp. 13-23.

30. de St Croix, T. Grassroots Youth Work. Policy, Passion and Resistance in Practice; Policy Press: Bristol, UK, 2016.

31. Stanton, N. (Ed.) Youth Work and Faith: Debates, Delights and Dilemmas; Russell House: Lyme Regis, UK, 2015.

32. Hamilton, D. The pedagogic paradox (or why no didactics in England?). Pedagog. Cult. Soc. 1999, 7, 135-152. [CrossRef]

33. Klein, J. The Study of Groups; Routledge and Kegan Paul: London, UK, 1956.

34. Klein, J. Working with Groups: The Social Psychology of Discussion and Decision; Hutchinson: London, UK, 1961.

35. Ministry of Education. The Youth Service in England and Wales. In The Albemarle Report; HMSO: London, UK, 1960. Available online: https:/ /infed.org/mobi/the-albemarle-report-introduction/ (accessed on 10 May 2021).

36. Goetchius, G.; Tash, M.J. Working with Unattached Youth: Problem, Approach, Method; Routledge and Kegan Paul: London, UK, 1967.

37. Davies, B.; Gibson, A. The Social Education of the Adolescent; University of London Press: London, UK, 1967.

38. Jeffs, A.J. Young People and the Youth Service; Routledge and Kegan Paul: London, UK, 1979; pp. 100-106.

39. Jeffs, T.; Smith, M. (Eds.) Welfare and Youth Work Practice; Macmillan: London, UK, 1988; pp. 112-132, $252-256$. 
40. Jeffs, T. What sort of future? In Innovation in Youth Work: Thinking in Practice; Stanton, N., Ed.; George Williams College: London, UK, 2015.

41. Jeffs, T. Contrasting Futures: An English perspective. In Youth Work: Global Futures; Bright, G., Pugh, C., Eds.; Brill Sense: Leyden, The Netherlands, 2019.

42. CACE (Central Advisory Council for Education). Children and Their Primary Schools Volumes 1 and 2. In The Plowden Report; HMSO: London, UK. Available online: http://www.educationengland.org.uk/documents/plowden/plowden1967-1.html (accessed on 16 May 2021).

43. Howes, V.M. Informal Teaching in the Open Classroom; Macmillan: New York, NY, USA, 1974; p. viii.

44. Button, L. Developmental Group Work with Adolescents; Hodder \& Stoughton: London, UK, 1976.

45. Galton, M.; Simon, B.; Croll, P. Inside the Primary Classroom; Routledge \& Kegan Paul: London, UK, 1980.

46. Barth, R.S. Open Education and the American School; Agathon: New York, NY, USA, 1972.

47. Pluckrose, H.A. Open School, Open Society; Evans: London, UK, 1975.

48. Weber, L. The English Infant School and Informal Education; Prentice-Hall: Englewood Cliffs, NJ, USA, $1971 ;$ p. 11.

49. Blyth, A. (Ed.) Informal Primary Education Today; Falmer: Lewes, DE, USA, 1988.

50. Allen, G.; Bastani, J.; Martin, I.; Richards, K. (Eds.) Community Education: An Agenda for Educational Reform; Open University Press: Milton Keynes, UK, 1987; pp. 10-11.

51. Fletcher, C.; Thompson, N. (Eds.) Issues in Community Education; Falmer Press: Lewes, DE, USA, 1980.

52. Loney, M. Community against Government. In The British Community Development Project 1968-78: A Study of Government Incompetence; Heinemann: London, UK, 1983.

53. Midwinter, E. Priority Education: An Account of the Liverpool Project; Penguin Education: Harmondsworth, UK, 1972.

54. Midwinter, E. Education and the Community; Allen \& Unwin: London, UK, 1975.

55. Lovett, T. Liverpool Educational Priority Area Project. In An Experiment in Adult Education in the EPA; Liverpool Educational Priority Area Project: Liverpool, UK, 1971.

56. Lovett, T. Adult Education, Community Development and the Working Class; Department of Adult Education, University of Nottingham: Nottingham, UK, 1982.

57. Lovett, T.; Clarke, C.; Kilmurray, A. Adult Education and Community Action; Croom Helm: London, UK, 1983.

58. HMSO. Adult Education, the Challenge of Change: Report (to the Scottish Education Department) by a Committee of Inquiry Appointed by the Secretary of State for Scotland under the Chairmanship of K.J.W. Alexander; HMSO: Edinburgh, UK, 1975.

59. Fordham, P. Informal, non-formal and formal education programmes in YMCA George Williams College ICE301. In Lifelong Learning, Unit 1 Approaching Lifelong Learning; YMCA George Williams College: London, UK. Available online: https: / infed.org/ mobi/informal-non-formal-and-formal-education-programmes/ (accessed on 15 May 2021).

60. Illich, I. Deschooling Society; Penguin Education: Harmondsworth, Middlesex, UK, 1971.

61. Freire, P. Pedagogy of the Oppressed; Penguin Education: Harmondsworth, UK, 1972.

62. Smith, M.K. What is Non-Formal Education? The Encyclopedia of Pedagogy and Informal Education. Available online: https://infed.org/mobi/what-is-non-formal-education/ (accessed on 3 August 2021).

63. Sennett, R. The Craftsman; Allen Lane: London, UK, 2008.

64. Korn, P. Why We Make Things and Why It Matters. The Education of a Craftsman; Square Peg/Vintage: London, UK, 2015.

65. Tett, G. The Silo Effect; Little Brown: London, UK, 2015.

66. Kahneman, D. Thinking Fast and Slow; Allen Lane: London, UK, 2011; p. 28.

67. Kirkwood, C. Vulgar Eloquence: From Labour to Liberation: Essays in Education, Community and Politics; Polygon: Edinburgh, Scotland, UK, 1990.

68. Martin, I. Signpost to nowhere in Community Education: The Making of an Empowering Profession, 3rd ed.; McConnell, C., Ed.; Community Learning Scotland: Edinburgh, UK, 2002; pp. 99-104.

69. Kirkwood, C. Key texts in community education. In Community Education: The Making of an Empowering Profession, 3rd ed.; McConnell, C., Ed.; Community Learning Scotland: Edinburgh, UK, 2002; p. 246.

70. Bradbury, A. Ability, Inequality and Post-Pandemic Schools. Rethinking Contemporary Myths of Meritocracy; Policy Press: Bristol, UK, 2021.

71. See Working and Learning Together to Build Stronger Communities (Scottish Executive Guidance for Community Learning and Development, 2004). In Influencing Change: Community Learning and Development in Scotland, 2001-2015; Ross, C. (Ed.) Community Learning and Development Standards Council for Scotland: Glasgow, UK, 2017.

72. Smith, M.K. Animate, Care, Educate-The Core Processes of Pedagogy. Available online: https://infed.org/mobi/animate-careeducate-the-core-processes-of-social-pedagogy / (accessed on 21 May 2021).

73. Mills, C.W. The Sociological Imagination; Oxford University Press: New York, NY, USA, 1959.

74. Steiner, G. Lessons of the Masters; Harvard University Press: Cambridge, MA, USA, 2003.

75. Sachs, J. Aristotle: Ethics. In The Internet Encyclopedia of Philosophy. Available online: https://www.iep.utm.edu/aris-eth/ (accessed on 19 July 2020).

76. Smith, M.K. Haltung, Pedagogy and Informal Education. Available online: https://infed.org/mobi/haltung-pedagogy-andinformal-education/ (accessed on 1 June 2021).

77. Steinweg, R. Brecht's Modell der Lehrstücke; Suhrkamp: Frankfurt, Germany, 1976. 
78. Smith, M.K. What is education? A definition and discussion. In The Encyclopedia of Pedagogy and Informal Education. Available online: https:/ /infed.org/mobi/what-is-education-a-definition-and-discussion/ (accessed on 21 May 2021).

79. Barrow, R. The decline of philosophy in educational study and why it matters. In The Importance of Philosophy in Teacher Education: Mapping the Decline and Its Consequences; Colgan, A.D., Maxwell, B., Eds.; Routledge: London, UK, 2020.

80. Palmer, P.J. The Courage to Teach, Exploring the Inner Landscape of a Teacher's Life; Jossey-Bass/Wiley: San Francisco, CA, USA, 2017; p. 10.

81. SPPA. Social Pedagogy Professional Association Standards; SPPA: London, UK, 2016. Available online: http://www.sppa-uk.org/ wp-content/uploads/2016/11/Social-pedagogy-standards.pdf (accessed on 22 May 2021).

82. Quintilian, M.F. Institutio Oratoria: Bok Two; Butler, H.E., Ed.; Harvard University Press: Cambridge, MA, USA, 1963.

83. Ellis, J. Christian youth work: Evangelism or social action? In Using Informal Education. An Alternative to Casework, Teaching and Control? Jeffs, T., Smith, M., Eds.; Open University Press: Milton Keynes, UK, 1990. Available online: https://infed.org/mobi/ christian-youth-work-evangelism-or-social-action/ (accessed on 1 June 2021).

84. Shuker, L.; Thompson, N. The 'Secular Culture' of Youth Work Training; Youthscape: Luton, UK, 2021.

85. Singer, P. Animal Liberation: Towards an End to Man's Inhumanity to Animals; Paladin: London, UK, 1975.

86. Fudge, E. Pets; Acumen Pub. Ltd.: Stocksfield, Northumberland, UK, 2008.

87. Oakeshott, M. Rationalism in Politics; Methuen: London, UK, 1962; p. 198.

88. Young, K. The Art of Youth Work; Russell House: Lyme Regis, UK, 2006.

89. Hume, D. Of Moral Prejudices in Essays: Moral, Political and Literary; The Liberty Fund: Indianapolis, IN, USA, 1984.

90. Howell, D. Training for Christian Youth and Children's Ministry in Decline, Why? Youthscape: Luton, Bedfordshire, UK, 2019. 